\title{
Empowering students' critical thinking skills, information literacy and cognitive learning outcome through RBL-TPS model
}

\author{
Siti S. Narahaubun ${ }^{a, 1}$, Johanis F. Rehena ${ }^{b, 2}$, Dominggus Rumahlatu b,3,* \\ a Study Program of Biology Education, Postgraduate, Universitas Pattimura, JI. Dr. Tamaela, Ambon, Maluku 97114, Indonesia \\ b Study Program of Biology Education, Faculty of Teacher Training and Education, Universitas Pattimura, Jl. Ir. M. Putuhena, Ambon, \\ Maluku 97233, Indonesia \\ ${ }^{1}$ sitisanianarahaubun@gmail.com ; 2 rehena.jf@gmail.com; ${ }^{3}$ dominggus_amq@yahoo.co.id \\ * Corresponding author
}

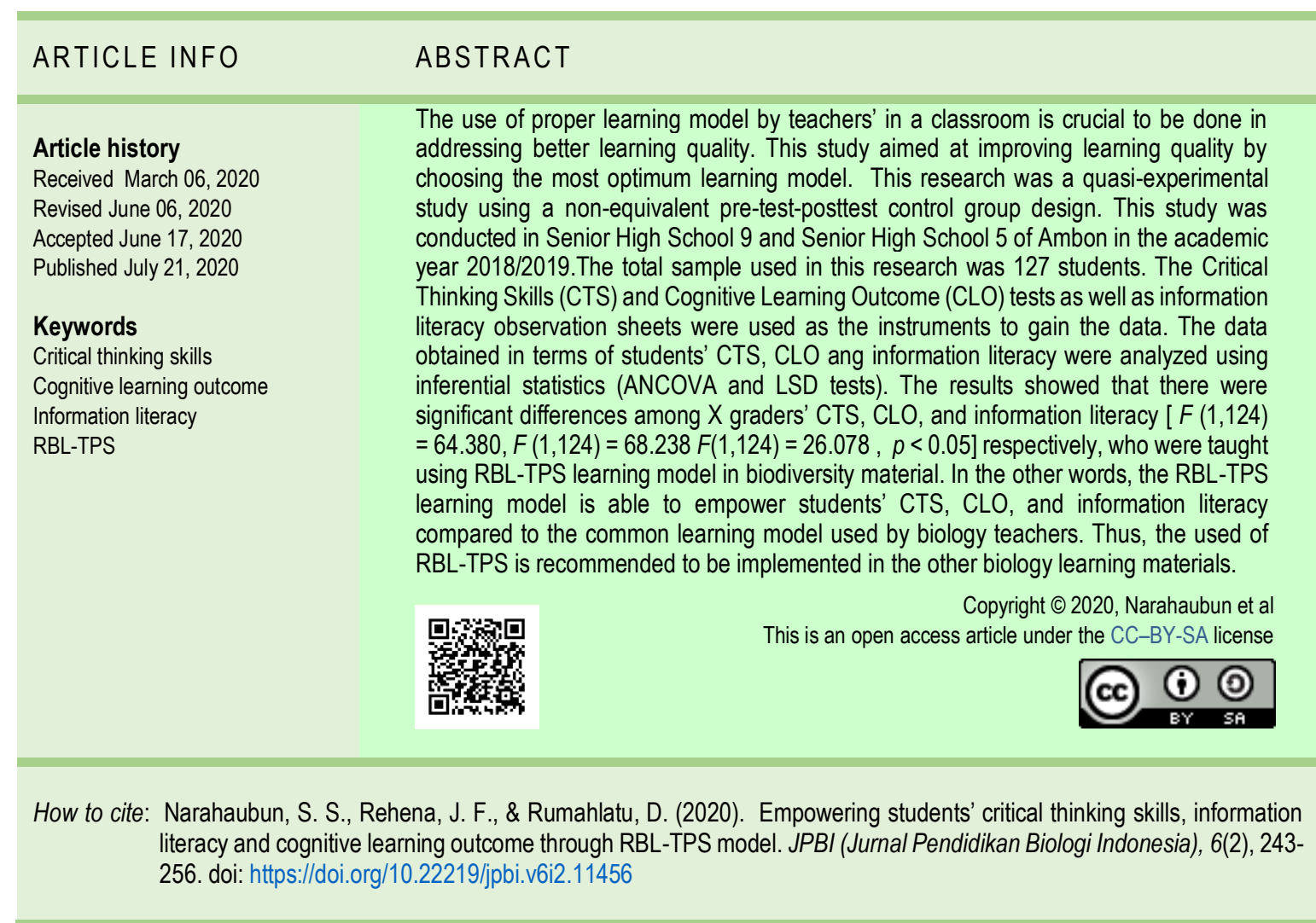

\section{INTRODUCTION}

Education is one of parts that affected by the industrial revolution (Azid, Hasan, Nazarudin, \& Md-Ali, 2020; Becker, Hornung, \& Woessmann, 2019; Ghozali, 2018). A similar idea is also stated by Benešová and Tupa (2017) that the industrial revolution has a high effect for the education of communities, where several professions will be altered by computer and Industry players must collaborate with universities so that the university graduates are able to answer the challenges of the industrial revolution. Departing from this idea, education is an area that should be given an extra concern in its current development. This is done so that the university graduates produced by higher education have the ability and competitiveness in the world of work. Lasi, Fettke, Kemper, Feld, and Hoffmann (2014) also add that industrial revolution has wide effect, in which it not only influences the 
industrial production but also labor market and education system. Sharma (2019) asserts that education in the Industrial Revolution 4.0 aims to improve teacher skills and student learning outcomes. Setiyawami, Sugiyo, Sugiyono, and Rahardjo (2019) propose that the impacts of Industrial Revolution 4.0 in education are to improve the students' skills in any aspects i.e. creativity, critical thinking, problem-solving skill, collaboration, and selfassessment. Kayembe and $\mathrm{Nel}$ (2019) also assume that the industrial revolution 4.0 brings many changes to the use of internet for various information literacy. The challenge confronted by biology teachers specifically in Ambon city is in implementing innovative learning to improve the student learning outcomes while developing other skills such as critical thinking and student information literacy. Therefore, biology teachers are still trying to improve the quality of learning so that the students are ready to encounter education 4.0.

One way to improve the quality of learning is by deciding on and using the right learning model to empower the students' skills. One of the learning models that is compatible to be implemented in the era of education 4.0 is Resource-Based Learning (RBL) model (Noguez \& Neri, 2019). Laverty (2000) emphasizes that the RBL learning model provides an opportunity for the students to look for information about concepts being studied, this can be an investigation of learning sources for the students since the process of seeking information is not only an individual task but it can be done during the learning process. Indeed, according to Vella (1997), the RBL is a learning model which a has wide learning sources and this model provides an opportunity for the students to be an independent learner. If the teachers use the RBL learning model, the teachers are able to direct the students in looking for information from various sources i.e. printed media and even no-printed media. Hill and Hannafin (2001) emphasize that learning sources can be in the form of primary and secondary learning sources. Learning sources which come from people, places, and ideas are called as primary learning sources, whereas learning sources that come from media are called as secondary learning sources. Resource-Based Learning (RBL) is a learning model that successfully develop information literacy skills so that the students are responsible for finding out and using the right material to be studied (Melendres, 2015). Additionally, the RBL learning model also has been combined with several learnings to improve student learning outcomes and learning quality. Febriani, Suratno, and Fikri (2015) combine the RBL learning model with a snowball throwing model, where the experimental class has better cognitive learning outcomes rather than the control class. Qoyyum, Jazim, and Linuhung (2017) report that the students who taught using RBL-Scramble have higher learning outcomes than the students who taught using conventional learning used by the teachers. Yaniwati, Kariadinata, Sari, Pramiarsih, and Mariani (2020) integrate the RBL along with online learning in order to improve the students' creative skill and self-confidence in mathematics learning. Saridewi, Suryadi, and Hikmah (2017) report that the student learning outcomes increase along with the use of discovery learning methods and learning experiences. In the interim, a study conducted by Ahmed and Khanam (2014) inform that the RBL learning model affects to the student learning outcomes.

The student learning outcomes are started by an understanding of a concept. Thru this understanding, the students train their basic thinking skills. The students who have good basic thinking can empower higher-order thinking, one of which is critical thinking. Facione (2010) enlightens critical thinking skills as an interpretation, analysis, conclusion, self-reinforcement skill. Based on Shanti, Sholihah, and Abdullah (2018) and McLaughlin and McGill (2017), critical thinking is a skill in making a rational decision against something that becomes a belief and it is done by the students. Taghva, Rezaei, Ghaderi, and Taghva (2014) emphasize that critical thinking skill also can give contribution on the students' cognitive ability. The students' critical skill can also develop since it is also influenced by the information gained by the students thru various sources i.e. through learning, reading digital or printed book, as well as newspaper and digital or printed magazines. Looking for information by means of printed sources and even digital can be interpreted as information literacy. Catts (2012) defines the information literacy as an ability to discover, evaluate, and utilize information to compile new knowledge Catts and Lau (2008) recommend that information literacy skill is developed in conjunction with Information and Communication Technology skills; thus, techniques to access and utilize information and cognitive abilities are needed.

In the last few years, several studies in the education field also use the Think-Pair-Share (TPS) learning model to discover the influences in improving the student learning outcomes (Hetika, Farida, \& Sari, 2017; Hamdan, 2017; Ogunyebi \& Henry, 2018; Rahayu \& Suningsih, 2018). Apriani (2016) clarifies that a learning using the TPS learning model can provide the students with plenty of time and attention to formulate individual ideas or thoughts before sharing the concepts studied with other students. Kaddoura (2013) enhances that active learning techniques in the TPS learning model can be used for the development of critical thinking. Other researchers have integrated the TPS learning model along with the Reading Concept Map (Remap) learning model and Guided Discovery which has succeeded in improving the student learning outcomes (Jatmiko, Kartina, Imandani, Fakhri, Pricilia, \& Rahayu, 2018; Bamiro, 2015). Additionally, Setiawati and Corebima (2018) assert that the integration of PQ4R-TPS learning model can improve the students' critical thinking skill. 
The integration of the RBL and TPS learning models on science learning in general and particularly in biology has never been done. Consequently, based on several combination studies of learning model that have been conducted previously, this study combines the RBL and TPS model in the material learning of biodiversity. Biodiversity material learns about the concept of the level of biodiversity in genes, species, and ecosystems. In studying these concepts, the students require information literacy skill, after finding out the information, the students will pick out and use the information. Thus, it is required a critical thinking from the students to divide good information and can answer the purpose of study from the teachers. If the information literacy skill and students' critical thinking have been performed, it will give influence in improving the student learning outcomes. Departing from the explanations above, the combination of RBL-TPS learning models is designed to be able to empower the cognitive, critical thinking, and information literacy skills possessed by the students to learn the material of biodiversity. Therefore, this study aims to discover the influence of RBL-TPS learning model to the student learning outcomes of cognitive, critical thinking, and information literacy skills in studying the biodiversity material. In the future, the results of this study can be used as a basis for study that combines the RBL-TPS learning model.

\section{METHOD}

This study was a quasi-experimental study to discover the influence of RBL-TPS model to the student learning outcomes of cognitive, critical thinking, and information literacy. Design of study used was non-equivalent pretest-posttest control group design (Table 1).

Table 1. Design of study

\begin{tabular}{llll}
\hline $\mathrm{E}$ & $\mathrm{Y} 1$ & $\mathrm{X} 1$ & $\mathrm{Y} 2$ \\
\hline $\mathrm{K}$ & $\mathrm{Y} 1$ & $\mathrm{X} 2$ & $\mathrm{Y2}$ \\
\hline
\end{tabular}

Description: E: experimental group; P: control group; Y1: pre-test; Y2: posttest; X1: STAD learning model; X2: RBL-TPS learning model

This study was carried out at SMA 9 Ambon and SMA 5 Ambon in the academic year of 2018/2019. The SMA 5 Ambon represented a school that was ISO certified and accredited A, while the SMA 9 Ambon represented as school that was not ISO certified and accredited B. Population of this study were whole students of $10^{\text {th }}$ grade at SMA Negeri 9 Ambon and SMA 5 Ambon. The samples of this study were detailed as follow; the students of X1- class consisting of 30 students and 29 students of X-2 class, whereas in the SMA 5 Ambon, there were 34 students from X-1 class and 34 students from the X-2 class; moreover, the total students that would be used as samples were 127 students. The sample determination of this study used purposive sampling technique based on the researchers' consideration that the class used as sample had characteristics based on the purpose of study with the provision that (1) the students were heterogeneous in terms of ethnicity, social, and gender; (2) availability of laptops, cellphones, and tablets to support literacy-based learning.

In each school, the students of X-1 class were taught using Student Teams Achievement Divisions (STAD) learning model. The students of X-2 class were taught using the RBL-TPS learning model with similar material, namely biodiversity. This was interpreted that data collection was carried out in four classes, and each class was conducted in 2 meetings.

The instruments used were test instruments in the form of essay items to measure the cognitive and critical thinking learning outcomes. However, scoring rubric to assess the cognitive learning outcomes and critical thinking was different. Scoring rubric for cognitive learning outcomes was developed by the researchers and referred to the answers and accompanied by complete, correct, and logical reasons. Scoring rubric of critical thinking emphasized on the criteria that (1) all concepts were correct, clear, and specific; (2) the argumentation was correct, clear, and specific, reinforced by strong reasons; (3) the flow of good thinking and concepts were interrelated; (4) the answer contained good and correct grammar (Zubaidah, Corebima, \& Mistianah, 2015). Another instrument used was not-test instrument in the form of observation sheets to assess the students' information literacy before and after the learning took place. Indicators of observation sheets of information literacy were enthusiasm, discovery, and selection of information, organization of information, use of information and communication (Catts \& Lau, 2008). The items were compiled referring to the competency standard based on the provisions of the National Education Standardization Agency (BSNP). 
The instrument used was first tested for validity and reliability. The validity test was used to determine the validity of each item and the content validator was the supervisor, while the reliability test was used to determine the consistency of the object measured using the Cronbach's Alpha method (Table 2).

Table 2. Data reliability test results

\begin{tabular}{ccc}
\hline Cronbach's Alpha & Items & Description \\
\hline 0.666 & 6 & Reliable \\
\hline
\end{tabular}

The stages of study for the implementation of learning material for environmental change were carried out almost simultaneously in each class and using different learning tools. The class $\mathrm{X}-1 /$ control class used the STAD learning model, in which it was a learning in several small groups, doing assignments from the teacher then doing quizzes independently at the end of the lesson. Meanwhile, the class X-2/experimental class used the RBL-TPS learning model. However, the assessment of students' cognitive skil, critical thinking, and information literacy variables remained the same. The stages of data collection in this study used two learning models whose stages were combined to form a new learning model, namely the stages of the RBL-TPS learning model (Table 3).

Table 3. Stages of RBL-TPS learning model

\begin{tabular}{|c|c|c|}
\hline RBL learning model & TPS learning model & RBL-TPS learning model \\
\hline $\begin{array}{l}\text { 1. Identifying questions or } \\
\text { problems } \\
\text { 2. Planning how to find out } \\
\text { information } \\
\text { 3. Gathering information } \\
\text { 4. Synthesizing information } \\
\text { 5. Evaluating } \\
\text { (Febriani et al., 2015) }\end{array}$ & $\begin{array}{l}\text { 1. Think: Independent thinking to a } \\
\text { question or problem given by the } \\
\text { teachers } \\
\text { 2. Pair: Pairing up with friends and } \\
\text { sharing the results of independent } \\
\text { thinking } \\
\text { 3. Share: Presenting paired results to the } \\
\text { class } \\
\text { (Ogunyebi \& Henry, 2018) }\end{array}$ & $\begin{array}{l}\text { 1. Identifying questions or problems } \\
\text { independently } \\
\text { 2. Planning how to find out information } \\
\text { independently } \\
\text { 3. Gathering information independently } \\
\text { 4. Synthesizing information independently } \\
\text { 5. Synthesizing information in pairs } \\
\text { 6. Evaluating }\end{array}$ \\
\hline
\end{tabular}

Before the implementation of learning began, the pre-test and observation sheets were given to the experimental and control class students. The results of prettest and the results of preliminary information literacy observations were used as covariates to measure the students' cognitive learning outcomes, critical thinking, and information literacy. Posttest and final observation assessment given to the experimental and control class students, carried out after the application of the learning model. The results of the posttest were used to measure the students' cognitive learning outcomes and critical thinking. The final observation sheet was used to assess the students' final literacy.

The data were analyzed using descriptive and inferential statistics. Descriptive statistics were used to determine the students' cognitive learning outcomes, critical thinking, and information literacy, where the data were grouped into class intervals and the frequency and percentage were calculated. Inferential statistics used the ANCOVA test to determine the influence of the RBL-TPS learning model on the students' cognitive learning outcomes, critical thinking, and information literacy. The test criteria for the ANCOVA test, namely if the probability or significance is $<0.05(p<0.05)$, it can be stated that there is an influence between the independent variables on the dependent variable partially, but if the significance is $>0.05(p>0.05)$, then it can be said that there is no significant influence between each independent variable on the dependent variable. Before the ANCOVA analysis was carried out, a prerequisite test was carried out, namely the normality and homogeneity test of the data. Then, the data were analyzed using the SPSS 18.0 program.

\section{RESULTS AND DISCUSSION}

\section{Students' critical thinking}

The results of study at SMA 9 Ambon (Table 4) showed that the distribution of critical thinking initial test scores in the control class was in the range of $43-60(100 \%)$, while the students' final test scores were in the 
range of $62-88(86.7 \%)$. For the students' critical thinking scores in the experimental class, the distribution of scores on the initial test was in the range of $47-58(100 \%)$, while the final test scores were in the range of $60-83$ $(100 \%)$. Furthermore, the results of the study at SMA 5 Ambon (Table 4) indicated that the distribution of students 'critical thinking initial test scores in the control class was in the range of 50-67 (100\%) $r$, while the students' final test scores were in the range of $61-76(49.6 \%)$. For the students' critical thinking scores in the experimental class, the distribution of scores on the initial test was in the range of $47-61(100 \%)$, while the final test scores were in the range of $70-94(100 \%)$. This meant that there is an increase in the score of students' critical thinking before and after the students are taught using conventional learning models and the RBL-TPS learning model at SMA 5 Ambon. Similar condition is shown by Tamara (2018) that there is a difference on the students' critical thinking before and after the learning using the implementation of learning model.

According to Rumahlatu, Sangur, and Liline (2020), the students who taught using CITP learning model are able to develop their critical thinking skills so that it is different from the students who taught using conventional learning model. This is different from a study conducted by Setiawati and Corebima (2018) who postulate that the TPS can be combined with PQ4R, in which it can improve the critical thinking skill. Likewise, a study conducted by Mahardini, Khaerunisa, Wijayanti, and Salimi (2018), It is revealed that the RBL model is able to improve critical thinking skills through authentic learning. The findings of this study indicated that the combination of the RBL-TPS learning model is able to improve the students' critical thinking, since the two syntaxes of the learning model are complementary and provide characteristics that distinguish these two learning models from the combination of other learning models.

Table 4. Student's critical thinking results

\begin{tabular}{|c|c|c|c|c|c|c|c|c|c|c|c|c|}
\hline \multirow{3}{*}{$\begin{array}{c}\text { School/research } \\
\text { class }\end{array}$} & \multicolumn{6}{|c|}{ Control class } & \multicolumn{6}{|c|}{ Experimental class } \\
\hline & \multicolumn{3}{|c|}{ Pretest } & \multicolumn{3}{|c|}{ Posttest } & \multicolumn{3}{|c|}{ Pretest } & \multicolumn{3}{|c|}{ Posttest } \\
\hline & Interval & $F$ & FR (\%) & Interval & $F$ & FR (\%) & Interval & $F$ & FR (\%) & Interval & $F$ & FR (\%) \\
\hline \multirow{6}{*}{ SMA 9 Ambon } & $43-45$ & 3 & 10 & $57-61$ & 4 & 13.3 & $47-48$ & 1 & 3.45 & $60-63$ & 2 & 6.9 \\
\hline & $46-48$ & 3 & 10 & $62-66$ & 12 & 40 & $49-50$ & 9 & 31 & $64-67$ & 3 & 10.3 \\
\hline & $49-51$ & 9 & 30 & $67-71$ & 9 & 30 & $51-52$ & 0 & 0 & $68-71$ & 7 & 24.1 \\
\hline & $52-54$ & 8 & 26.67 & $72-76$ & 2 & 6.67 & $53-54$ & 14 & 48.3 & $72-75$ & 7 & 24.1 \\
\hline & $55-57$ & 4 & 13.33 & $77-81$ & 2 & 6.67 & $55-56$ & 0 & 0 & $76-79$ & 7 & 24.1 \\
\hline & $58-60$ & 3 & 10 & $82-86$ & 1 & 3.33 & $57-58$ & 5 & 17.2 & $80-83$ & 3 & 10.3 \\
\hline Total & & 30 & 100 & & 30 & 100 & & 29 & 100 & & 29 & 100 \\
\hline \multirow{6}{*}{ SMA 5 Ambon } & $50-52$ & 12 & 35.3 & $53-56$ & 1 & 2.94 & $47-49$ & 4 & 11.8 & $70-74$ & 6 & 17.6 \\
\hline & $53-55$ & 9 & 26.5 & $57-60$ & 16 & 47.1 & $50-52$ & 9 & 26.5 & $75-79$ & 7 & 20.6 \\
\hline & $56-58$ & 11 & 32.4 & $61-64$ & 6 & 17.6 & $53-55$ & 6 & 17.6 & $80-84$ & 18 & 52.9 \\
\hline & $59-61$ & 1 & 2.94 & $65-68$ & 6 & 17.6 & $56-58$ & 8 & 23.5 & $85-89$ & 1 & 2.94 \\
\hline & $62-64$ & 0 & 0 & $69-72$ & 2 & 5.88 & $59-61$ & 7 & 20.6 & $90-94$ & 2 & 5.88 \\
\hline & $65-67$ & 1 & 2.94 & $73-76$ & 3 & 8.82 & & & & & & \\
\hline Total & & 34 & 100 & & 34 & 100 & & 34 & 100 & & 34 & 100 \\
\hline
\end{tabular}

\section{Students' information literacy skills}

The results of study at SMA 9 Ambon (Table 5) showed that the distribution of the initial scores of students' information literacy skills in the control class was in the range of 33-44 (100\%), while the final scores of students' information literacy skills were in the range of $83-100(100 \%)$. For the information literacy scores of students in the experimental class, the distribution of the initial scores was in the range of $33-41(100 \%)$, while the final scores were in the range of 83-100 (100\%). Additionally, the results of study at SMA 5 Ambon (Table 5) indicated that the distribution of the initial scores of students 'information literacy skills in the control class was in the range of 33-44 (100\%), while the final scores of students' information literacy skills were in the range of $83-100 .(100 \%)$. For the information literacy scores of students in the experimental class, the distribution of the initial scores was in the range of $33-50(100 \%)$, while the final scores were in the range of $83-100(100 \%)$. This meant that there is an increase in the score of students' information literacy before and after the students are taught using conventional models and the RBL-TPS learning model at SMA 9 Ambon and SMA 5 Ambon. This occurs since the assessment to the information literacy skill affects the student learning outcomes (Saptasari, Sunarmi, Sulasmi, Wicaksono, \& Sudraja, 2019), as well as the students' behavior to the information literacy that significantly affect on the students' information literacy and their perception about information literacy (Adekunle, Olla, Olajide, Osuji, \& Adedoyin, 2019). This is different from a study conducted by Rufiana and Mulyadi (2017) that the TPS learning model can be modified to be TPSS (Think, Pair, Share, and Square) and it can improve the critical thinking, cooperation, listening, and writing. The advantage of the combination of the RBL-TPS 
learning model is that it can train the students to do information literacy and think independently; then, make pairs and share information with peers.

Table 5. Student's information literacy skill results

\begin{tabular}{|c|c|c|c|c|c|c|c|c|c|c|c|c|}
\hline \multirow{3}{*}{$\begin{array}{l}\text { School/research } \\
\text { class }\end{array}$} & \multicolumn{6}{|c|}{ Control Class } & \multicolumn{6}{|c|}{ Experimental Class } \\
\hline & \multicolumn{3}{|c|}{ Initial Assessment } & \multicolumn{3}{|c|}{ Final assessment } & \multicolumn{3}{|c|}{ Initial Assessment } & \multicolumn{3}{|c|}{ Final Assessment } \\
\hline & Interval & $F$ & FR (\%) & Interval & $\mathbf{F}$ & FR (\%) & Interval & $\mathbf{F}$ & FR (\%) & Interval & $\mathbf{F}$ & FR (\%) \\
\hline \multirow{6}{*}{ SMA 9 Ambon } & $33-35$ & 28 & 93.3 & $83-85$ & 9 & 30 & $33-35$ & 23 & 79.3 & $83-85$ & 2 & 6.9 \\
\hline & $36-38$ & 0 & 0 & $86-88$ & 0 & 0 & $36-38$ & 0 & 0 & $86-88$ & 0 & 0 \\
\hline & $39-41$ & 1 & 3.33 & $89-91$ & 7 & 23.3 & $39-41$ & 6 & 20.7 & $89-91$ & 9 & 31.03 \\
\hline & $42-44$ & 1 & 3.33 & $92-94$ & 9 & 30 & & & & $92-94$ & 13 & 44.82 \\
\hline & & & & $95-97$ & 0 & 0 & & & & $95-97$ & 0 & 0 \\
\hline & & & & $98-100$ & 5 & 16.7 & & & & $98-100$ & 5 & 17.25 \\
\hline Total & & 30 & 100 & & 30 & 100 & & 29 & 100 & & 29 & 100 \\
\hline \multirow{6}{*}{ SMA 5 Ambon } & $33-35$ & 16 & 47.1 & $83-85$ & 2 & 5.88 & $33-35$ & 13 & 38.2 & $83-85$ & 1 & 2.94 \\
\hline & $36-38$ & 0 & 0 & $86-88$ & 6 & 17.6 & $36-38$ & 0 & 0 & $86-88$ & 0 & 0 \\
\hline & $39-41$ & 16 & 47.1 & $89-91$ & 7 & 20.6 & $39-41$ & 13 & 38.2 & $89-91$ & 1 & 2.94 \\
\hline & $42-44$ & 2 & 5.88 & $92-94$ & 0 & 0 & $42-44$ & 7 & 20.6 & $92-94$ & 11 & 32.4 \\
\hline & & & & $95-97$ & 19 & 55.9 & $45-47$ & 0 & 0 & $95-97$ & 0 & 0 \\
\hline & & & & $98-100$ & 34 & 100 & $48-50$ & 1 & 2.94 & $98-100$ & 21 & 61.8 \\
\hline Total & & 34 & 100 & & 2 & 5.88 & & 34 & 100 & & 34 & 100 \\
\hline
\end{tabular}

\section{Student cognitive learning outcomes}

The results of the study at SMA 9 Ambon (Table 6) showed that the distribution of the students 'cognitive pretest scores in the control class was in the range of 40-60 (93.33\%), while the students' cognitive posttest were in the range of $64-83(76.7 \%)$. For the students' cognitive scores in the experimental class, the distribution of scores on the pre-test was in the range of 50-67 (100\%), while the posttest scores were in the range of 66-95 (86.2\%). In addition, the results of the study at SMA 5 Ambon (Table 6) indicated that the distribution of students 'cognitive pre-test scores in the control class was in the range of 30-64 (100\%), while the students' posttest scores were in the range of $45-80(100 \%)$. For the students' initial cognitive test scores in the experimental class, the distribution of students' scores on the pre-test was in the range of 50-67 (100\%), while the posttest scores were in the range of 70-99 (100\%). This meant that there is an increase in student cognitive learning outcomes before and after the students are taught using the STAD model and the RBL-TPS learning model at SMA 9 Ambon and SMA 5 Ambon. However, the increase in learning outcomes before and after the application of the RBL-TPS learning model was higher than the application of the STAD learning model.

Table 6. Student cognitive learning outcomes

\begin{tabular}{|c|c|c|c|c|c|c|c|c|c|c|c|c|}
\hline \multirow{3}{*}{$\begin{array}{c}\text { School/research } \\
\text { class }\end{array}$} & \multicolumn{6}{|c|}{ Control class } & \multicolumn{6}{|c|}{ Experimental class } \\
\hline & \multicolumn{3}{|c|}{ Pretest } & \multicolumn{3}{|c|}{ Posttest } & \multicolumn{3}{|c|}{ Pretest } & \multicolumn{3}{|c|}{ Posttest } \\
\hline & Interval & $\mathbf{F}$ & FR (\%) & Interval & $F$ & FR (\%) & Interval & $\mathbf{F}$ & FR (\%) & Interval & $F$ & FR (\%) \\
\hline \multirow{6}{*}{ SMA 9 Ambon } & $40-44$ & 2 & 6.67 & $60-63$ & 7 & 23.3 & $50-52$ & 2 & 6.89 & $60-65$ & 4 & 13.8 \\
\hline & $41-45$ & 3 & 10 & $64-67$ & 8 & 26.7 & $53-55$ & 3 & 10.34 & $66-71$ & 3 & 10.3 \\
\hline & $46-50$ & 10 & 33.33 & $68-71$ & 9 & 30 & $56-58$ & 0 & 0 & $72-77$ & 13 & 44.8 \\
\hline & $51-55$ & 5 & 16.67 & $72-75$ & 2 & 6.67 & $59-61$ & 10 & 34.48 & $78-83$ & 8 & 27.6 \\
\hline & $56-60$ & 8 & 26.67 & $76-79$ & 0 & 0 & $62-64$ & 0 & 0 & $84-89$ & 0 & 0 \\
\hline & $61-65$ & 2 & 6.67 & $80-83$ & 4 & 13.3 & $65-67$ & 14 & 48.28 & $90-95$ & 1 & 3.45 \\
\hline Total & & 30 & 100 & & 30 & 100 & & 29 & 100 & & 29 & 100 \\
\hline \multirow{6}{*}{ SMA 5 Ambon } & $30-35$ & 1 & 2.941 & $45-50$ & 6 & 17.6 & $50-52$ & 6 & 17.65 & $70-74$ & 6 & 17.6 \\
\hline & $36-41$ & 0 & 0 & $51-56$ & 9 & 26.5 & $53-55$ & 3 & 8.824 & $75-79$ & 15 & 44.1 \\
\hline & $42-47$ & 1 & 2.941 & $57-62$ & 6 & 17.6 & $56-58$ & 0 & 0 & $80-84$ & 5 & 14.7 \\
\hline & $48-53$ & 13 & 38.24 & $63-68$ & 6 & 17.6 & $59-61$ & 14 & 41.18 & $85-89$ & 2 & 5.88 \\
\hline & $54-59$ & 5 & 14.71 & $69-74$ & 6 & 17.6 & $62-64$ & 0 & 0 & $90-94$ & 3 & 8.82 \\
\hline & $60-64$ & 14 & 41.18 & $75-80$ & 1 & 2.94 & $65-67$ & 11 & 32.35 & $95-99$ & 3 & 8.82 \\
\hline Total & & 34 & 100 & & 34 & 100 & & 34 & 100 & & 34 & 100 \\
\hline
\end{tabular}

A study of Siregar, Susilo, and Suwono (2017), also show that the TPS learning which combined with TTW affects to the students' cognitive learning outcomes. A study conducted by Awaluddin (2019) also reveals that the RBL learning model can improve the student learning outcomes. Thus, the RBL-TPS learning model is more effective in improving the students' cognitive learning outcomes, since it has special characteristics i.e. learning 
sources, then independent thinking, pairs and report the results of the paired discussion in class discussion. The RBL-TPS learning model can also activate the students in the learning process. The constructivist learning model can make all students actively involved during the learning process (Rofieq, Latifa, Susetyarini, \& Purwatiningsih, 2019).

The influence of RBL-TPS learning model to the critical thinking skills, information literacy, and cognitive learning outcomes

Prerequisite test

After knowing the scores of students' critical thinking, information literacy, and cognitive, then it was continued to the normality test of data using Kolmogorov-Smirnov test. The results indicated that the data were normally distributed, while the Levene test indicated that the data came from a homogeneous population (Table 7).

Table 7. Homogeneity test results and data normality

\begin{tabular}{|c|c|c|c|c|c|c|c|c|}
\hline \multirow[b]{2}{*}{ Variables } & \multirow[b]{2}{*}{ Score } & \multicolumn{4}{|c|}{ Levene statistic } & \multicolumn{3}{|c|}{ Kolmogorov-Smirnova } \\
\hline & & Sig. & $\begin{array}{l}\text { Level of } \\
\text { confidence }\end{array}$ & Description & Score & Sig. & $\begin{array}{l}\text { Level of } \\
\text { confidence }\end{array}$ & Description \\
\hline Critical thinking & .530 & .468 & \multirow{3}{*}{$\alpha=0.05$} & \multirow{3}{*}{$\begin{array}{l}\text { Homogen } \\
\text { eous }\end{array}$} & 1.257 & .085 & \multirow{3}{*}{$\alpha=0.05$} & \multirow{3}{*}{ Normal } \\
\hline Information literacy & 1.342 & .091 & & & 1.716 & .090 & & \\
\hline $\begin{array}{l}\text { Cognitive learning } \\
\text { outcomes }\end{array}$ & 2.113 & .149 & & & 1.475 & .066 & & \\
\hline
\end{tabular}

\section{Hypothesis test}

The results of ANCOVA test to the students' critical thinking after being given a learning using conventional learning model and the RB-TPS learning model, it was shown in the Table 8 and an advanced test of LSD was shown in the Table 9, as the following:

Table 8. The results of critical thinking hypothesis test

\begin{tabular}{lrrrrr}
\hline \multicolumn{1}{c}{ Source } & $\begin{array}{c}\text { Type III sum of } \\
\text { squares }\end{array}$ & df & Mean square & F & Sig. \\
\hline Corrected Model & $4662.994^{\mathrm{a}}$ & 2 & 2331.497 & 68.464 & .000 \\
Intercept & 4199.201 & 1 & 4199.201 & 123.309 & .000 \\
kritis_awal & 430.079 & 1 & 430.079 & 12.629 & .001 \\
model_pembelajaran & 2323.817 & 1 & 2323.817 & 68.238 & .000 \\
Error & 4222.746 & 124 & 34.054 & & \\
Total & 628388.889 & 127 & & & \\
Corrected Total & 8885.739 & 126 & & & \\
\hline
\end{tabular}

Table 9. Advanced test results of critical thinking

\begin{tabular}{lccc}
\hline & Learning model & Mean & LSD notation \\
\hline Conventional & 64.1146 & $\mathrm{a}$ \\
RBL-TPS & 75.6614 & $\mathrm{~b}$ \\
\hline
\end{tabular}

The ANCOVA test results (Table 8) showed that the $F_{\text {value was }} 68,238$ with a significant value of $0.00<0.05$. Based on these results, then $\mathrm{H} 0$ was rejected and $\mathrm{H} 1$ was accepted. This meant that there is an influence of the learning model on students' critical thinking. In addition, the LSD advanced test results (Table 9) showed that there is a notation difference between the conventional learning model used in the control class (notation a) and the RBL-TPS learning model used in the experimental class (notation b). This proved that the students who were taught using the RBL-TPS learning model had better critical thinking skills than the students who were taught using conventional learning models, both at SMA 5 Ambon and SMA 9 Ambon. These findings are reinforced by a statement of Birgili (2015) a learning model using problem-solving activity can improve the students' critical thinking skills. In the RBL-TPS also emerge a problem-solving activity thru an information discovery and independent thinking and then information sharing to the peers, as well as continued to the 
second meeting that is biodiversity observation. Meanwhile, in the conventional learning, activities emerge up are discussion and presentation using STAD learning model.

Based on Sinprakob and Songkram (2015), critical thinking must be continuously empowered so that it becomes a habit for students' daily lives. The stages in the RBL-TPS learning model are a combination of learning stages that are able to empower critical thinking skills which include a good flow of thinking and able to link various concepts of biodiversity. Rusmansyah, Ibrahim, Isnawati, and Prahani (2019) argue that systematic learning stages help the students to remember the steps to empower critical thinking. The independent information search stage helps the students to practice as critical thinkers to find out and use that information to form a logical flow of thinking. Furthermore, the students are also trained to convey arguments when thinking independently to their partners and when doing the stages of thinking with their partners. The critical thinking stage is also trained in the second meeting, which is when observing the components of biodiversity in the environment, the students will use correct concept of biodiversity and be able to link various types of biodiversity into an understanding. The same opinion is conveyed by Susiani, Salimi, and Hidayah (2018) and Boleng (2015) that critical thinking is a skill to analyze, evaluate, synthesize information from an accurate source, use information properly in the digital era as well. Amin, Corebima, and Zubaidah (2017) assert that someone who think critically will able to ask question, link relevant information effectively and efficiently, organize information creatively and rationally, and establish consistent conclusions.

The implementation of RBL assists the students to actively participate in learning and the students are given an opportunity to learn not only from the material delivered by the teachers, but also being active in the literature discovery, formulating hypotheses, collecting data, analyzing/testing the data, and drawing conclusions (Susiani et al., 2018). Thus, if the RBL-TPS learning model is used in the learning, then the students have passed the information synthesis process to be a flow of thinking so as to form critical arguments independently, share arguments with partners, link various concepts of biodiversity through observation, then communicate paired results to other group friends. These various activities help the students to develop critical thinking skills so that the students can use critical thinking skills in answering the final test. Confirmed by Flores, Matkin, Burbach, Quinn, and Harding (2012) and Kabataş Memiş and Çakan Akkaş (2020) that the ability to think critically can be used by the students to express opinions and correct friends' opinions based on scientific justification.

The results of the ANCOVA test on student information literacy after being given a learning with conventional learning models and the RBL-TPS learning model were shown in Table 10 and the results of the LSD advanced test were shown in Table 11, as follows.

Table 10. Information literacy hypothesis test results

\begin{tabular}{lrrrrr}
\hline \multicolumn{1}{c}{ Source } & $\begin{array}{c}\text { Type III sum of } \\
\text { squares }\end{array}$ & df & Mean square & F & Sig. \\
\hline Corrected Model & $808.148^{\mathrm{a}}$ & 2 & 404.074 & 15.280 & .000 \\
Intercept & 9504.734 & 1 & 9504.734 & 359.429 & .000 \\
literasi_awal & 25.693 & 1 & 25.693 & .972 & .326 \\
model_pembelajaran & 689.614 & 1 & 689.614 & 26.078 & .000 \\
Error & 3279.049 & 124 & 26.444 & & \\
Total & 1102530.864 & 127 & & & \\
Corrected Total & 4087.197 & 126 & & & \\
\hline
\end{tabular}

Table 11. Advanced test results of information literacy

\begin{tabular}{lccc}
\hline & Learning model & Mean & LSD notation \\
\hline Conventional & 91.0590 & $\mathrm{a}$ \\
RBL-TPS & 95.5026 & $\mathrm{a}$ \\
\hline
\end{tabular}

The ANCOVA test results (Table 10) showed that the $F_{\text {value }}$ was 26,078 with a significant value of $0.00<0.05$. Based on these results, then $\mathrm{H} 0$ was rejected and $\mathrm{H} 1$ was accepted. This meant that there is an effect of the learning model on students' information literacy skills. In addition, the results of the LSD advanced test (Table 11) showed that there is no notation difference between the conventional learning model used in the control class and the RBL-TPS learning model used in the experimental class. This proved that the students who were taught using the RBL-TPS and conventional learning models were equally able to develop their information literacy skills, both at SMA 5 Ambon and SMA 9 Ambon. This happens because the students in this digital era 
have been able to use gadgets to search for information so that between the conventional learning model and the RBL-TPS learning model there is no difference. According to Tuamsuk (2013), information literacy is a skill to respond an information need, the needs of each individual are different tailored to their information needs. Martin (2013) argues that in this digital era, the function of information literacy is to use and disseminate information ethically, but requires the ability to cope with changing information. Moreover, the information literacy is predicted by Internet experience, Internet skills of information seeking, sharing, and verification, attitude towards information verification, and belief in the reliability of information that influenced the role of individuals as media gatekeepers who verify the internet information (Khan \& Idris, 2019).

According to Kuhlthau (1987), educators need to train information literacy to the students so that they are proficient in interpreting information and using information wisely. This is done by educators so that the students do not take complete information from a source, without giving the name of the source and choosing the correct information to be used. The way that educators can do is to use the right learning model. Melendres (2015) explains that the RBL is a learning model that can develop information literacy skills through responsible information discovery. Therefore, if the RBL learning model is combined with the TPS learning model, the students can search for information then think independently and in pairs; moreover, the students still include sources of information so that they train the students not to become plagiarism from an early age. Singh, Kaur, and Brar (2017) emphasize that the students who understand technology will need the latest information, so the students must be prepared with the skills to identify and retrieve this information.

The ANCOVA test results on students' cognitive learning outcomes after being given learning with conventional learning models and the RBL-TPS learning model were shown in Table 12 and the LSD advanced test results were shown in Table 13, as follows.

Table 12. Cognitive learning outcomes hypothesis test results

\begin{tabular}{lrrrrr}
\hline \multicolumn{1}{c}{ Source } & \multicolumn{1}{c}{$\begin{array}{c}\text { Type III sum of } \\
\text { squares }\end{array}$} & df & Mean square & F & Sig. \\
\hline Corrected Model & $5525.828^{\mathrm{a}}$ & 2 & 2762.914 & 44.818 & .000 \\
Intercept & 5872.820 & 1 & 5872.820 & 95.265 & .000 \\
pre_tes & 32.938 & 1 & 32.938 & .534 & .466 \\
model_pembelajaran & 3968.839 & 1 & 3968.839 & 64.380 & .000 \\
Error & 7644.251 & 124 & 61.647 & & \\
Total & 638975.000 & 127 & & & \\
Corrected Total & 13170.079 & 126 & & & \\
\hline
\end{tabular}

Table 13. Advanced test results of cognitive learning outcomes

\begin{tabular}{lccc}
\hline & Learning model & Mean & LSD notation \\
\hline Conventional & 63.6719 & $\mathrm{a}$ \\
RBL-TPS & 76.8254 & $\mathrm{~b}$ \\
\hline
\end{tabular}

The ANCOVA test results (Table 12) showed that the $F_{\text {value }}$ was 64,380 with a significant value of $0.00<0.05$. Based on these results, $\mathrm{H} 0$ was rejected and $\mathrm{H} 1$ was accepted. This meant that there is an effect of the learning model on student cognitive learning outcomes. In addition, the LSD advanced test results (Table 13) showed that there is a notation difference between the conventional learning model used in the control class (notation a) and the RBL-TPS learning model used in the experimental class (notation b). This proved that the students who were taught using the RBL-TPS learning model had better mastery of concepts than the students taught using conventional learning models, both at SMA 5 Ambon and SMA 9 Ambon. This indicated that the RBLTPS learning model was more effective in increasing the students' mastery of concepts compared to the learning model commonly used by the teachers so far (control class). The stages in the RBL-TPS learning model provided a freedom for students to use learning resources independently and these learning resources were not limited to teachers or printed books, but they could use various learning resources such as newspapers, magazines, interview sheets, environment, websites and the internet, videos and pictures. After that, the students synthesized the learning resources independently, the next step was to synthesize reading results in pairs with friends. At this time, there could be an exchange of information between peers. 
Nugraha (2018) assumes that the RBL learning model emphasizes the activities of students to look for unlimited learning resources via the internet and textbooks so that the teachers are not only a source of learning for students. Furthermore, Boleng (2015) explains that The TPS learning model emphasizes an independence, cooperates with each other, strengthens, completes so that each student during the discussion has the initial capital to argue with each other, fill in, find solutions, and be able to make conclusions on a problem. Therefore, the combination of these two learning models focuses on finding learning resources and processing information independently then sharing information with peers to solve problems. These findings are also similar with the findings provided by Khaeriyah, Warsiti, and Kartika (2015) regarding the combination of resource-based learning models with the scientific approach, the results can improve academic achievement in mastering the material, attitudes and students' critical thinking, while Bahtiar (2013) assumes that TPS learning model combined with RQA can provide better results in increasing mastery of Biology concepts. In addition, seeking information from various sources trains the students to learn independently so that the material being studied can be understood by the students, since the students themselves find this knowledge through searching from various sources of information. Mariyam and Nuraida (2017) postulate that conceptual formation can be done thru incubation stage and memory insertion, these two stages will strengthen or stabilze the students' concepts about the material presented so that maximum learning outcomes are obtained.

\section{CONCLUSION}

Departing from the results of study, it can be concluded that the RBL-TPS learning model improve critical thinking skills, information literacy, and studuents' cognitive learning outcomes. The score improvement of critical thinking, information literacy, and students' cognitive are better in the experimental class compared to the control class. In the SMA 9 Ambon, the score of studuents'critical thinking is improved from 58 to, the score of students' information literacy is improved from 58 to 83 , and the score of students' cognitive learning outcomes is improved from 67 to 95 . In the SMA 5 Ambon, the score of studuents' critical thinking is improved from 61 to 94 , the score of students' information literacy is improved from 50 to 100, and the score of students' cognitive learning outcomes is improved from 67 to 99 . Additionally, the results of ANCOVA test found that there is an influence on the RBL-TPS learning model to the students' critical thinking skills, information literacy, and cognitive learning outcomes at SMA 9 Ambon and SMA 5 Ambon $(0.00<0.05)$. The information obtained from the results of this study is a new learning syntax, namely a syntax of RBL-TPS model so that the biology teachers can implement the RBL-TPS model in other biological concepts.

\section{ACKNOWLEDGEMENT}

Gratitude goes to the Governor of Maluku who has given permission for teachers to continue their studies at the Biology Education Study Program, Postgraduate at the Pattimura University, Academic Year of 2017/2018.

\section{REFERENCES}

Adekunle, A. P., Olla, G. O. O., Olajide, A. A., Osuji, C. N., \& Adedoyin, A. O. (2019). Attitude of undergraduate students to information literacy: Bowen university experience. Journal of Balkan Libraries Union, 6(1), $1-$ 11. Retrieved from http://balkanlibraries.org/frontend/Journal/pdf/Article1_Attitude of Undergraduate Students to Information Literacy Bowen University Experience_2.pdf

Ahmed, O., \& Khanam, M. (2014). Learning resources management strategies and academic achievement of secondary school students. The International Journal of Indian Psychology, 2(1), 108-119. doi: https:/l doi.org/10.25215/0201.014

Amin, A. M., Corebima, A. D., \& Zubaidah, S. (2017). The critical thinking skills profile of preservice biology teachers in animal physiology. Proceedings of the 3rd International Conference on Education and Training, 128(179-183). doi: https://doi.org/10.2991/icet-17.2017.30 
Apriani, E. (2016). Using the think-pair-share (TPS) strategy to enhance students' reading achievement of the seventh grade at MTSN Lumpatan. Jurnal Pendidikan Islam, 1(2), 189-204. doi: https://doi.org/10.292 40/bjpi.v1i2.110

Awaluddin. (2019). Resource-based learning for teaching Arabic. Journal of Arabic Learning, 2(1), 77-91. doi: https://doi.org/10.18860/ijazarabi.v2i1.6612

Azid, N., Hasan, R., Nazarudin, N. F. M., \& Md-Ali, R. (2020). Embracing industrial revolution 4.0: The effect of using web 2.0 tools on primary schools students' mathematics achievement (fraction). International Journal of Instruction, 13(3), 711-728. doi: https://doi.org/10.29333/iji.2020.13348a

Bahtiar. (2013). Potensi pembelajaran yang memadukan strategi think pairs share (TPS) dan reading questioning answering (RQA) untuk meningkatkan sikap sosial dan penguasaan konsep biologi siswa SMA multietnis di Ternate. Prosiding Seminar Nasional Biologi, 10(2), 1-7. Retrieved from doi: https://jurnal.fkip.uns.ac.id/index.php/prosbio/article/view/3132

Bamiro, A. O. (2015). Effects of guided discovery and think-pair-share strategies on secondary school students' achievement in chemistry. Sage Open, 1-7. doi: https://doi.org/10.1177/2158244014564754

Becker, S. O., Hornung, E., \& Woessmann, L. (2009). Catch me if you can: Education and catch-up in the industrial revolution. IZA Discussion Paper No. 4556. Forschungsinstitut Zur Zukunft Der Arbeit Institute for the Study of Labor, 5, 1-59. Retrieved from https://www.cesifo.org/DocDL/cesifo1_wp2816.pdf

Benešová, A., \& Tupa, J. (2017). Requirements for education and qualification of people in industry 4.0. Procedia Manufacturing, 11, 2195-2202. doi: https://doi.org/10.1016/j.promfg.2017.07.366

Birgili, B. (2015). Creative and critical thinking skills in problem-based learning environment. Journal of Gifted Education and Creativity, 2(2), 71-80. doi: https://doi.org/10.18200/JGEDC.2015214253

Boleng, D. T. (2015). Pengaruh penggunaan model pembelajaran think-pair-share terhadap Keterampilan berpikir kritis, hasil belajar kognitif bakteriologi mahasiswa program studi pendidikan biologi FKIP universitas mulawarman. In Seminar Nasional XII Pendidikan Biologi FKIP UNS (pp. 572-579). Retrieved from http://repository.unmul.ac.id/handle/123456789/4254

Catts, R. (2012). Indicators of adult information literacy. Journal of Information Literacy, 6(2), 4-18. doi: https://doi.org/10.11645/6.2.1746

Catts, R., \& Lau, J. (2008). Towards information literacy indicators. Paris: UNESCO. Retrieved from doi: https://dspace.stir.ac.uk/bitstream/1893/2119/1/cattsandlau.pdf

Facione, P. A. (2011). Critical thinking: What it is and why it counts. Insight assessment. Insight assessment. Retrieved from https://www.kritischdenkenhbo.n//files/uploads/2019/1566550466789-what \& why critical thinking, update 2015.pdf

Febriani, R., Suratno, \& Fikri, K. (2015). Pengaruh model pembelajaran resource based learning (RBL) dikombinasikan dengan snowball throwing terhadap metakognisi dan hasil belajar biologi. Jurnal Edukasi, 2(2), 26-32. doi: https://doi.org/10.19184/jukasi.v2i2.3507

Flores, K. L., Matkin, G. S., Burbach, M. E., Quinn, C. E., \& Harding, H. (2012). Deficient critical thinking skills among collage graduates: Implication for leadership. Educational Philosophy and Theory, 44(2), 212229. doi: https://doi.org/10.1111/j.1469-5812.2010.00672.x

Ghozali, I. (2018). Educational challenges to the 4.0 industrial revolution: Experience from Indonesia. The International Academin Seminar, 1-7. Retrieved from: http://ustjogja.ac.id/journal/download/4th_In dustrial_Revolution.pdf

Hamdan, R. K. A. (2017). The Effect of (think-pair-share) strategy on the achievement of third grade student in sciences in the educational district of Irbid. Journal of Education and Practice, 8(9), 88-95. Retrieved from https://eric.ed.gov/?id=EJ1139082

Hetika, H., Farida, I., \& Sari, Y. P. (2017). Think Pair Share (TPS) as Mmethod to improve student's learning motivation and learning achievement. Dinamika Pendidikan, 12(2), 125-135. doi: https://doi.org/10. 15294/dp.v12i2.13561

Hill, J. R., \& Hannafin, M. J. (2001). Teaching and learning in digital environments: The resurgence of resourcebased learning. Education Technology Research Development, 49(3), 37-52. doi: https://doi. org/10.1007/BF02504914 
Jatmiko, A., Kartina, Y., Irwandani, Fakhri, J., Pricilia, A., \& Rahayu, T. (2018). Reading concept map-think pair share (remap-TPS) learning model on cognitive ability and scientific attitude. Tadris: Jurnal Keguruan Dan IImu Tarbiyah, 3(2), 183-195. doi: https://doi.org/10.24042/tadris.v3i2.3184

Kabataş Memiş, E., \& Çakan Akkaş, B. N. (2020). Developing critical thinking skills in the thinking-discussionwriting cycle: the argumentation-based inquiry approach. Asia Pacific Education Review, 21(3), 441-453. doi: https://doi.org/10.1007/s12564-020-09635-z

Kaddoura, M. (2013). Think pair share: A teaching learning strategy to enhance students' critical thinking. Educational Research Quarterly, 36(4), 3-24. Retrieved from https://eric.ed.gov/?id=EJ1061947

Kayembe, C., \& Nel, D. (2019). Challenges and opportunities for education in the fourth industrial revolution. African Journal of Public Affairs, 11(3), 79-94. Retrieved from https://journals.co.za/content/journal/ 10520/EJC-19605d342e

Khaeriyah, E., Warsiti, \& Kartika, C. S. (2015). Penerapan model resource based learning (RBL) dengan pendekatan scientific dalam peningkatan pembelajaran IPA di kelas IV SDN 1 Klapasawit tahun ajaran 2014/2015. Alam Cendekia, 3(5), 551-555. Retrieved from https://www.google.com/url?sa=t

Khan, M. L., \& Idris, I. K. (2019). Recognise misinformation and verify before sharing: a reasoned action and information literacy perspective. Behaviour and Information Technology, 38(12), 1194-1212. doi: https://doi.org/10.1080/0144929X.2019.1578828

Kuhlthau, C. C. (1987). Information skills for an information society: A review of research. Retrieved from https://eric.ed.gov/?id=ED297740

Lasi, H., Fettke, P., Kemper, H. G., Feld, T., \& Hoffmann, M. (2014). Industry 4.0. Business \& Information Systems Engineering, 6, 239-242. doi: https://doi.org/10.1007/s12599-014-0334-4

Laverty, C. C. (2000). Resource-based learning: Gateway to information literacy. Retrieved from https://www.researchgate.net/publication/309763067_Resource-Based_Learning_Gateway_to_Informat ion_Literacy

Mahardini, T., Khaerunisa, F., Wijayanti, I. W., \& Salimi, M. (2018). Research based learning (RBL) to improve critical thinking skills. SHEs: Conference Series, 1(2), 466-473. doi: https://doi.org/10.20961/shes.v1i2. 26816

Mariyam, \& Nuraida, D. (2017). Pengaruh model pembelajaran brain based learning dipadukan dengan mind mapping terhadap penguasaan konsep siswa. Proceeding Biology Education Conference, 4(1), 494-497. Retrieved from https://jurnal.uns.ac.id/prosbi/article/view/18482

Martin, J. (2013). Refreshing information literacy learning from recent british information literacy models. Communications in Information Literacy, 7(2), 114-127. doi: https://doi.org/10.15760/comminfolit.2013. 7.2.142

McLaughlin, A. C., \& McGill, A. E. (2017). Explicitly teaching critical thinking skills in a history course. Science \& Education, 26(1-2), 93-105. doi: https://doi.org/10.1007/s11191-017-9878-2

Melendres, G. O. (2015). Resource-based learning (RBL) strategy to improve information literacy in general science of freshmen secondary students. In Proceeding of the 3rd Global Summit on Education GSE (pp. 290-297). Retrieved from https://worldconferences.net/proceedings/gse2015

Noguez, J., \& Neri, L. (2019). Research-based learning: a case study for engineering students. International Journal on Interactive Design and Manufacturing (IJIDeM), 13(4), 1283-1295. doi: https://doi.org/ 10.1007/s12008-019-00570-x

Nugraha, M. (2018). Penerapan model pembelajaran resource based learning (RBL) dalam upaya meningkatkan kemampuan penguasaan konsep IPA. Mendidik: Jurnal Kajian Pendidikan Dan Pengajaran, 4(1), 71-76. doi: https://doi.org/10.30653/003.201841.45

Ogunyebi, \& Henry, T. (2018). Enhancing science performance through think-pair strategies among college of education students in integrated science in Ekiti State, Nigeria. International Journal of Education and Evaluation, 4(4), 55-66. Retrieved from https://iiardpub.org/get/IJEE/VOL. 4 NO. 4 2018/ENHANCING SCIENCE.pdf

Qoyyum, I. M., Jazim, \& Linugung, N. (2017). Pengaruh pendekatan resource based learning dikombinasikan scramble terhadap hasil belajar siswa. In Prosiding Seminar Nasional Pendidikan (pp. 66-72). Palembang. Retrieved from https://www.google.com/url?sa=t\&rct 
Rahayu, S., \& Suningsih, A. (2018). The effects of type learning model numbered head together and think pair share. International Journal of Trends in Mathematics Education Research, 1(1), 19. doi: https://doi.org/ 10.33122/ijtmer.v1i1.27

Rofieq, A., Latifa, R., Susetyarini, E., \& Purwatiningsih. (2019). Project-based learning: Improving students' activity and comprehension through lesson study in senior high school. Jurnal Pendidikan Biologi Indonesia, 5(1), 41-50. doi: https://doi.org/10.22219/jpbi.v5i1.7456

Rufiana, D., \& Mulyadi. (2017). Using think-pair-square-share strategy to improve students' speaking ability for Indonesian senior high school students. Journal of Applied Linguistics and Literature, 2(1), 1-11. doi: https://doi.org/10.33369/joall.v2i1.5872

Rumahlatu, D., Sangur, K., \& Liline, S. (2020). The effect of complex instruction team product (CITP) learning model on increase student's skills. International Journal of Instruction, 13(1), 587-606. doi: https:/l doi.org/10.29333/iiji.2020.13138a

Rusmansyah, Y., Ibrahim, L., Isnawati, M., \& Prahani, B. K. (2019). Innovative chemistry learning model: Improving the critical thinking skill and self-efficacy of pre-service chemistry teachers. Journal of Technology and Science Education, 9(1), 59-76. doi: https://doi.org/10.3926/jotse.555

Saptasari, M., Sunarmi, S., Sulasmi, E. S., Wicaksono, R., \& Sudrajat, A. K. (2019). Information literacy skill: An alternative to support biology student's learning outcomes. Jurnal Pendidikan Biologi Indonesia, 5(3), 451-458. doi: https://doi.org/10.22219/jpbi.v5i3.8768

Saridewi, N., Suryadi, J., \& Hikmah, N. (2017). The implementation of discovery learning method to increase learning outcomes and motivation of student in senior high school. Jurnal Penelitian Dan Pembelajaran IPA, 3(2), 124-133. doi: https://doi.org/10.30870/jppi.v3i2.782

Setiawati, H., \& Corebima, A. D. (2018). Improving students' metacognitive skills through science learning by integrating PQ4R and TPS strategies at a senior high school in Parepare, Indonesia. Journal of Turkish Science Education, 15(2), 95-106. doi: https://doi.org/10.12973/tused.10233a

Setiyawami, Sugiyo, Sugiyono, \& Rahardjo, T. J. (2019). The industrial revolution 4.0 impact on vocational education in Indonesia. In Iconect (pp. 1-5). doi: https://doi.org/10.4108/eai.20-8-2019.2288089

Shanti, W. N., Sholihah, D. A., \& Abdullah, A. A. (2018). Pengaruh pendekatan problem posing dan CTL terhadap kemampuan berpikir kritis dalam pembelajaran matematika bagi siswa SMA. Jurnal Karya Pendidikan Matematika, 5(2), 49-57. doi: https://doi.org/10.26714/jkpm.5.2.2018.49-57

Sharma, P. (2019). Digital revolution of education 4.0. International Journal of Engineering and Advanced Technology, 9(2), 3558-4564. doi: https://doi.org/10.35940/ijeat.A1293.129219

Singh, B., Kaur, A., \& Brar, K. S. (2017). Information literacy and learning styles: An overview of resource-based studentcentred learning. Journal of Management Research and Analysis, 4(3), 84-86. doi: https://doi.org/10.18231/2394-2770.2017.0012

Sinprakob, S., \& Songkram, N. (2015). A proposed model of problem-based learning on social media in cooperation with searching technique to enhance critical thinking of undergraduate students. ProcediaSocial and Behavioral Sciences, 174, 2027-2030. doi: https://doi.org/10.1016/j.sbspro.2015.01.871

Siregar, I. Y., Susilo, H., \& Suwono, H. (2017). Pengaruh think-pair-share-Write berbasis hybrid learning terhadap keterampilan metakognitif, berpikir kreatif dan hasil belajar kognitif siswa SMA negeri 3 Malang. Jurnal Pendidikan Biologi Indonesia, 3(2), 135-142. doi: https://doi.org/10.22219/jpbi.v3i2.4217

Susiani, T. S., Salimi, M., \& Hidayah, R. (2018). Research based learning (RBL): How to improve critical thinking skills?. SHS Web of Conferences (Vol. 42, pp. 2-6). doi: https://doi.org/10.1051/shsconf/201 84200042

Taghva, F., Rezaei, N., Ghaderi, J., \& Taghva, R. (2014). Studying the relationship between critical thinking skills and students' educational achievement (eghlis universities as case study). International Letters of Social and Humanistic Science, 25, 18-25. doi: https://doi.org/10.18052/www.scipress.com/LSHS.25. 18

Tamara, T. (2018). Pengaruh penerapan metode think-pair-share dan group investigation terhadap kemampuan berpikir kritis siswa. Indonesian Journal of Economics Education, 1(1), 73-84. Retrieved from https://ejournal.upi.edu/index.php/IJEE/article/view/10789/6625

Tuamsuk, K. (2013). Information literacy instruction in Thailand higher education. Procedia-Social and Behavioral Sciences, 73, 145-150. doi: https://doi.org/10.1016/j.sbspro.2013.02.034

Vella, F. (1997). Resource-based learning. Biochemical Education, 25(2), 113. doi: https://doi.org/10.1016/ S0307-4412(97)88299-4 
Yaniwati, P., Kariadinata, R., Sari, N. M., Pramiarsih, E. E., \& Mariani, M. (2020). Integration of e-learning for mathematics on resource based learning: Increasing mathematical creative thinking and self-confidence. International Journal of Emerging Technologies in Learning, 15(6), 60-78. doi: https://doi.org/10.3991/ ijet.v15i06.11915

Zubaidah, S., Corebima, A. D., \& Mistianah. (2015). Asesmen berpikir kritis terintegrasi tes essay. Symposium on Biology Education on Prosiding, 200-213. Retrieved from https://pbio.uad.ac.id/unduh/prosidingsymbion-2015/ 